\title{
Biochemical composition and somatic growth of pelagic larvae of three fish species from the Bay of Biscay
}

\author{
E. Díaz ${ }^{1, *}$ J. M. Txurruka ${ }^{2}$, F. Villate ${ }^{3}$ \\ ${ }^{1}$ AZTI Arrantza Baliabideen Saila, Txatxarramendi ugartea, z/g. 48395 Sukarrieta, Bizkaia, Spain \\ ${ }^{2}$ University of the Basque Country, Department of Genetics, Physical Anthropology and Animal Physiology, 48080 Bilbao, Spain \\ ${ }^{3}$ University of the Basque Country, Department of Plant Biology and Ecology, 48080 Bilbao, Spain
}

\begin{abstract}
The growth strategies of pelagic larvae of 3 fish species from the Bay of Biscay belonging to 2 different shape groups, the eel-like anchovy Engraulis encrasicolus and sardine Sardina pilchardus, and the tadpole-like horse mackerel Trachurus trachurus, are compared in terms of changes in their biochemical composition and energy allocation. In anchovy and sardine, the relative amount of protein increased and relative amounts of carbohydrates and lipids decreased throughout their growth. The biochemical composition in horse mackerel did not change significantly during growth. Differences between the 2 shape groups could be associated with the various energy allocation patterns related to dissimilar growth strategies. Although the patterns of change in biochemical composition during growth are different in the 2 shape groups, they show a very similar biochemical composition at the notochord flexion stage, indicating convergences in life-history patterns of the different species.
\end{abstract}

KEY WORDS: Anchovy - Sardine $\cdot$ Horse mackerel $\cdot$ Fish larvae $\cdot$ Biochemical composition · RNA/DNA · Growth strategy

Resale or republication not permitted without written consent of the publisher

\section{INTRODUCTION}

Successful recruitment is crucial to increasing the size of a population and it is well known that mortality at early stages of development determines recruitment variability in fishes (Cushing 1990, Leggett \& Deblois 1994). Inter-annual variability in the recruitment of some small and medium pelagic species seems to affect population dynamics much more strongly than the eventual effects of variations in fishing intensity (Southward et al. 1988, Sharp \& McLain 1993). Therefore, for the proper management of these fisheries, it is essential to understand the mechanisms that govern year-to-year fluctuations in abundance and year-class strength of small and medium pelagics.

Although the relative significance of individual recruitment mechanisms is not clear, it is commonly accepted that starvation as well as predation determine larval mortality. Fish larvae are forced to adopt strategies to avoid both starvation and predation in order to increase their survival probability. According to the 'growth mortality hypothesis' (Hare \& Cowen
1997), faster growing larvae may be able to gain advantages by shortening a developmental phase (the 'stage-duration' mechanism; Houde 1987) if, as a consequence, larval death probability due to starvation and/or predation decreases (the 'biggger is better' mechanism, Miller et al. 1988). Therefore, larvae should allocate a considerable amount of energy to favour optimal growth rates.

However, in organisms living in seasonally changing environments, there must be trade-offs between energy allocation to growth, predation avoidance, and the storage of enough reserves to overcome periods of resource scarcity or energy demanding stages. Smallbodied animals are faced with strong competing demands for surplus energy, since they have the highest rates of food consumption, growth, respiration and risk of starvation (Post \& Parkinson 2001). Fish larvae devoting all their energy to growth might be able to swim more efficiently, avoid predation and have a broader prey spectrum. But if larvae did not store some energy, they would not survive periods of resource scarcity, such as northern temperate winters. Contrary 
to expectations of the bigger-is-better hypothesis (Miller et al. 1988), Gagliano et al. (2007) found that, if large enough energy reserves were available, there was no apparent disadvantage for small-sized fish at hatching. Additionally, larvae allocating all their energy to growth would not be able to face up to energy demanding stages, such as metamorphosis, when changes in morphology, physiology and behaviour consume a large amount of lipids (Nursall 1989).

Larvae of different fish species differ in their morphology, their developmental status at hatching, and in their physiological or behavioural capabilities (Miller et al. 1988). Those specific characteristics, together with the environmental circumstances that each larva experiences, would determine the best energy allocation strategy to increase larval fitness, i.e. its ability to survive and reproduce. Thus, larvae will allocate variable resource proportions towards the conflicting demands of energy storage (basically lipids) and/or somatic growth (mostly proteins). During early growth of anchovy Engraulis encrasicolus and sardine Sardina pilchardus, larvae tend to achieve an 'optimal proportion' of biochemical constituents that increase larval survival (Díaz 2008, Díaz et al. 2008). In this context, the quantitative comparison of the rate of accretion of the various biochemical constituents in different species, or in the diverse size-classes of the same species, is a particularly useful approach for testing growth predictions, as well as for analysing the various strategies of energy allocation relative to survival probability.

The study of the early developmental stages of anchovy, sardine and horse mackerel Trachurus trachurus is extremely interesting since they show very variable annual recruitment and are among the 3 most important commercial pelagic species for the Bay of Biscay fishery. Anchovy and sardine belong to the 'eellike' larvae shape group (Froese 1990, Estensoro 2006) and horse mackerel to the 'tadpole-like' group. The eel-like larvae have a large body length, small body section and small heads, whilst the tadpole-like larvae have a short body and large heads. Larval shape is an indicator of the different growth strategies of fish larvae (Froese 1990); so differences in growth-related indices and in energy allocation strategies are expected between the eel-like and the tadpole-like larval groups, which will be reflected in differences in the accretion of various biochemical components. The aims of the present study are (1) to analyse the accretion dynamics of various biochemical constituents during larval growth of anchovy, sardine and horse mackerel, because they are key factors in the understanding of the different larval energy allocation strategies, and (2) to examine the ecological implications of such strategies with respect to how they might be linked to body shape.

\section{MATERIALS AND METHODS}

Study area and sampling. Temperature and food availability are the main factors affecting growth and nucleic acid-based indices of fish larvae in the sea (Esteves et al. 2000, Caldarone 2005). To eliminate the possible effects of these factors in the comparisons, only the larvae of anchovy, sardine and horse mackerel obtained during the same month (June 2001) were included in the present study. Sampling was conducted at 3 stations (D1, D2 and D3) on a cross-shelf transect in the Bay of Biscay on the Basque continental shelf off San Sebastian (Fig. 1). In this area, the climate is temperate with moderate winters and warm summers. Since the shelf is very narrow, hydrological conditions are highly variable, resulting from the mixing of coastal, shelf and open ocean waters.

Larvae were captured using oblique tows with a $40 \mathrm{~cm}$ diameter bongo fitted with a $335 \mu \mathrm{m}$ mesh net. All tows were performed during daytime and above the thermocline, to maximize the number of larvae collected (Palomera 1991). To describe and compare environmental conditions, temperature and salinity were measured at 4 evenly distributed depths from the surface to the depth of the thermocline. To determine food availability, the concentration of microparticles (20 to $200 \mu \mathrm{m}$ ) and the presence of the main prey of fish larvae (copepod eggs, nauplii, and copepodites) were determined (Last 1980). These prey samples were obtained by towing a 25 $\mathrm{cm}$ diameter, $20 \mu \mathrm{m}$ mesh net from above the thermocline up to the surface. No significant differences among the 3 stations were found in the average value of environmental conditions above the thermocline. The concentration of total microplankton and the specific main prey items for fish larvae increased from inshore to offshore stations. A more detailed description of the environmental sampling methodology and data may be found in Díaz et al. (2007).

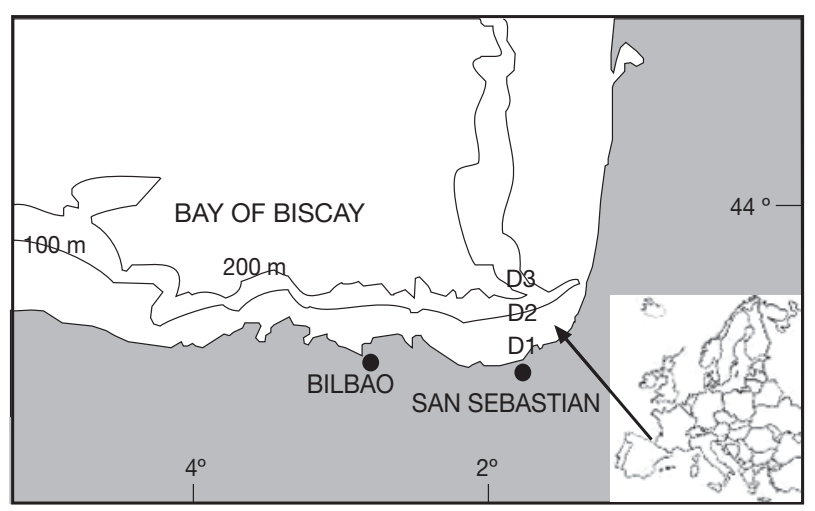

Fig. 1. Location of the sampling points in the Bay of Biscay. D1, D2, D3: sample stations. Depths and distance to coast $(\mathrm{m} / \mathrm{km})$ : D1 (60/2.8); D2 (120/16.7); D3 (250/29.6). 100 and $200 \mathrm{~m}$ depth contours are shown 
Laboratory work. Standard lengths $(\mathrm{SL}, \mathrm{mm}$ ) of thawed larvae were measured using a binocular microscope fitted with an ocular micrometer. Since the number of larvae from each individual sampling station was insufficient to allow statistical comparisons between stations, larvae from the 3 stations (D1, D2 and D3) were grouped for each species.

Three subsamples of larvae were taken from each species and used to estimate (1) organic matter (OM) content (anchovy $\mathrm{n}=31$, sardine $\mathrm{n}=22$, horse mackerel $\mathrm{n}=28$ ); (2) proteins, carbohydrates, and lipids (anchovy $\mathrm{n}=24$, sardine $\mathrm{n}=31$, horse mackerel $\mathrm{n}=32$ ); and (3) RNA and DNA contents (anchovy $\mathrm{n}=27$, sardine $n=23$, horse mackerel $n=28$ ). All larvae were first rinsed with distilled water (to eliminate salt) and freeze-dried; afterwards, dry weight was determined with a Sartorius M3P microbalance. The first subsamples of larvae were ashed at $450^{\circ} \mathrm{C}$ for $4 \mathrm{~h}$ and $\mathrm{OM}$ content was calculated as the difference between dry weight (DW) and ash weight. Larvae of the second subsample were used to quantify proteins, carbohydrates and lipids colorimetrically. Proteins were measured according to the Lowry et al. (1951) method, modified by Markwell et al. (1978), using bovine serum albumin as the standard. Lipids were extracted following the Bligh \& Dyer (1959) method and quantified with the sulfophosphovanillin method of Zöllner \& Kirsch (1962), with cholesterol as the standard. Carbohydrates were quantified following the procedure of Dubois et al. (1956), using glucose as the standard. Larvae of the third subsample were used to determine nucleic acid contents (DNA and RNA), which were quantified following the protocol proposed by the precision and accuracy of tools in recruitment studies (PARS project, www.efan.no/pars/) after several intercalibration trials (Belchier et al. 2004). The mean ratio between the slopes of the standard curves for DNA and RNA (DNA/RNA) was $2.65 \pm 0.025$. A more detailed description of the laboratory work may be found in Díaz et al. (2008).

Data treatment. The energy allocation strategy during growth of the 3 species was determined by modelling the rate of accretion of biochemical constituents. Differences in accretion rates were examined using various approaches: (1) analysis and comparison of the isometric or allometric increase in each biomolecule and species relative to $\mathrm{OM}$ increase using log-log equations; (2) measurement of the relative amount of each biomolecule and the RNA/DNA ratio change in relation to OM during growth; and (3) between-species comparison of nucleic acid accretion using ANCOVA.

The relationships between DW and SL, together with $\mathrm{OM}$ and SL, were best fitted by an exponential model $[D W=a \exp (b S L)]$ in anchovy and sardine and by a potential model $\left(\mathrm{DW}=\mathrm{a} \mathrm{SL}^{\mathrm{b}}\right)$ in the case of horse mack- erel (Fig. 2). These equations were subsequently used to estimate the OM of larvae in the protein, carbohydrate, lipid, and nucleic acid analyses.

ANCOVA was used to compare the log-log regression models. Species was the independent (categorical) variable, and the logarithm of proteins, carbohydrates, lipids, DNA and RNA were the dependent variables. Log OM was the covariate. Slope values close to 1 indicate a basically isometric growth pattern, whilst slope values $<1$ and $>1$ indicate a negative and positive allometric dependence with $\mathrm{OM}$, respectively.

To analyse how the relative importance of each biomolecule and the RNA/DNA ratio changes in relation to OM during growth, experimental data were fitted to a 2-parameter hyperbolic function. The hyperbolic functions were used to estimate the theoretical biochemical composition of anchovy and sardine larvae at their notochord flexion stages. In horse mackerel, as no variation trend was found in the biomolecules during growth, the average composition of the larvae around notochord flexion (5.75 to $6.25 \mathrm{~mm}$ ) was used to estimate the composition in the notochord flexion larvae. In anchovy, the flexion of the notochord occurs at 9 to $10 \mathrm{~mm}$ (Ré 1996), in sardine at 11 to $12.5 \mathrm{~mm}$ (Ré 1984), and in horse mackerel at $6 \mathrm{~mm}$ (Russell 1976), so the average SL at the notochord flexion stages were used (9.5 for anchovy and 11.5 for sardine). Finally, any structure is considered to be full-grown when it has reached a size equal to $95 \%$ of its asymptotic value (Amenzoui et al. 2006), thus the larval OM content and the SL corresponding to this content were calculated for anchovy and sardine.

To compare the variations in the RNA/DNA ratio (dependent variable) throughout growth in the 3 spe-

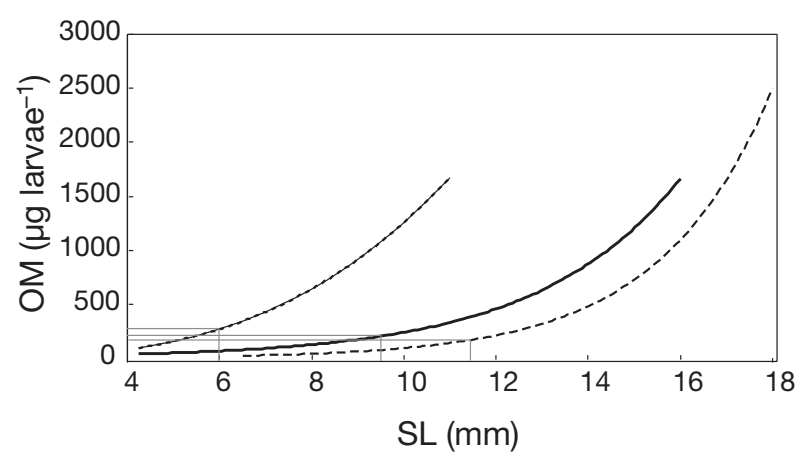

Fig. 2. Engraulis encrasicolus, Sardina pilchardus and Trachurus trachurus. Relationship of standard length (SL) and organic matter (OM) content of larvae. Mean SL and corresponding $\mathrm{OM}$ at notochord flexion are indicated. Engraulis encrasicolus $(-)$ : dry weight $(\mathrm{DW}, \mathrm{mg})=0.0151 \mathrm{e}^{0.3097 \mathrm{SL}}, \mathrm{r}^{2}=$ 0.913 and OM $(\mathrm{mg})=0.0094 \mathrm{e}^{0.3234 \mathrm{SL}}, \mathrm{r}^{2}=0.711(\mathrm{n}=31) ;$ Sardina pilchardus $(---)$ : DW $(\mathrm{mg})=0.0019 \mathrm{e}^{0.4309 \mathrm{SL}}, \mathrm{r}^{2}=0.924$ and OM $\left.(\mathrm{mg})=0.0015 \mathrm{e}^{0.4120 \mathrm{SL}} \mathrm{r}^{2}=0.899,(\mathrm{n}=22)\right)$; Trachurus trachurus (---): DW $(\mathrm{mg})=0.0017 \mathrm{SL}^{3.0218}, \mathrm{r}^{2}=0.934$ and $\mathrm{OM}$ $(\mathrm{mg})=0.0012 \mathrm{SL}^{3.0200}, \mathrm{r}^{2}=0.901(\mathrm{n}=28)$ 
cies (independent variable), ANCOVA was used, with SL as a covariate. Similarly, the RNA content (dependent variable) in the 3 species (independent variable) was compared with larval DNA content as a covariate. When no significant differences were found between species for a given biomolecule, a common equation was calculated for this biomolecule using the entire data set. All statistical analyses were performed using Statgraphics Plus 5.0. The significance level was set at $\mathrm{p}<0.05$.

\section{RESULTS}

The size distribution and developmental stages differed between species (Fig. 3). Horse mackerel larvae were smaller than anchovy and sardine larvae, but more horse mackerel larvae were in their postflexion stage $(55 \%)$ than anchovy $(35.3 \%)$ and sardine $(46.3 \%)$ larvae.

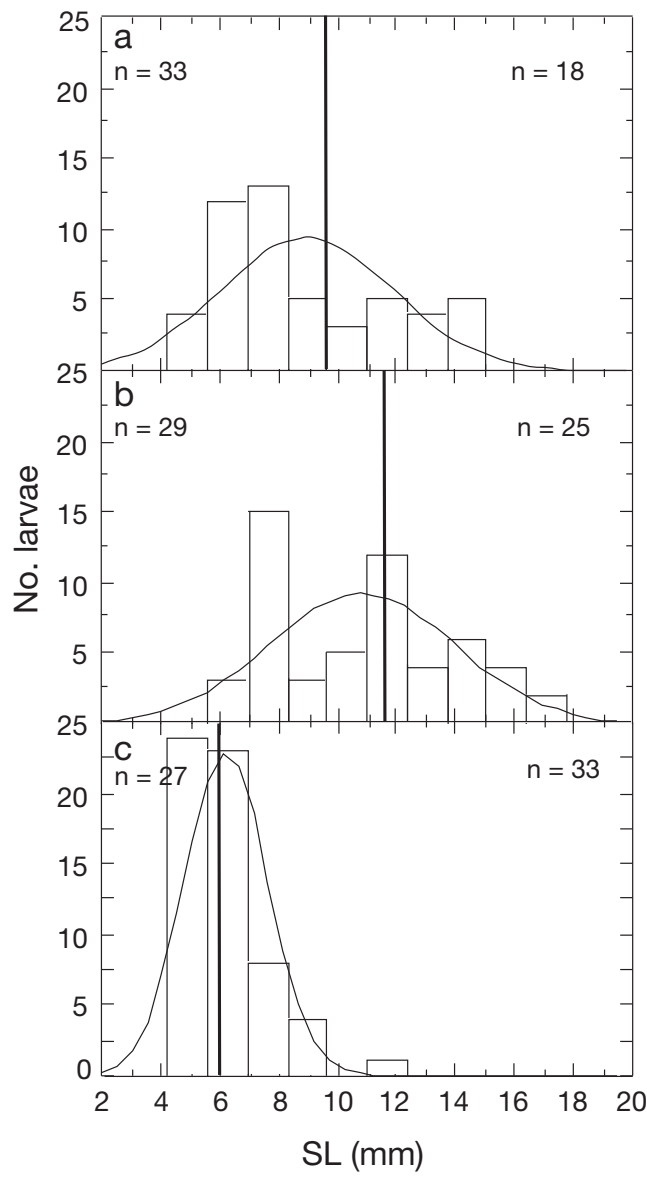

Fig. 3. Size frequency distribution for standard length (SL) of (a) Engraulis encrasicolus, (b) Sardina pilchardus and (c) Trachurus trachurus larvae used in the biochemical composition analysis. The vertical line shows the mean size of notochord flexion. The number (n) of larvae before and after notochord flexion is indicated

\section{Biochemical composition of larvae}

The slopes and the intercepts of the regressions relating biochemical constituents to OM were significantly different among species in most cases (Table 1), but there were several exceptions: (1) the intercepts and the slopes of the equations relating DNA to OM were not significantly different between anchovy and sardine; (2) equations relating carbohydrates and lipids to OM were not significantly different between anchovy and horse mackerel (Tukey's test, $\mathrm{p}>0.05$ ). In each of those 3 cases, a single equation with the same slope and intercept was calculated for both species (Table 2). Additionally, the slopes of the regressions relating proteins to OM were not significantly different between anchovy and sardine; thus, we cal-

Table 1. Engraulis encrasicolus, Sardina pilchardus and Trachurus trachurus. ANCOVAs to test the effect of species on biomolecule composition (log ng larva ${ }^{-1}$ ) with organic matter (log OM ng larva ${ }^{-1}$ ) as a covariate. CHs: Carbohydrates.

\begin{tabular}{|lrrrr|}
\hline & \multicolumn{2}{c}{ Intercept } & \multicolumn{2}{c|}{ Slope } \\
& \multicolumn{1}{c}{ F } & \multicolumn{1}{c|}{$\mathrm{p}$} & \multicolumn{1}{c|}{${ }^{2}$} & \multicolumn{1}{c}{$\mathrm{p}$} \\
\hline Proteins & 27.7 & $<0.0001$ & 10.7 & $<0.0001$ \\
CHs & 70.9 & 0.0007 & 40.0 & 0.0210 \\
Lipids & 25.5 & $<0.0001$ & 70.5 & 0.0010 \\
DNA & 40.1 & 0.0201 & 10.0 & 0.0001 \\
RNA & 13.7 & $<0.0001$ & 70.6 & 0.0010 \\
& & & & \\
\hline
\end{tabular}

Table 2. Engraulis encrasicolus, Sardina pilchardus, and Trachurus trachurus. Equations relating OM (lg ng larva ${ }^{-1}$,) and biochemical composition. Prot: proteins; $\mathrm{CH}$ : carbohydrates; Lip: lipids. CI: confidence interval. Note: all of the regressions had $\mathrm{p}$ values $<0.0001$

\begin{tabular}{|lcc|}
\hline Equation & CI slope & $\mathrm{r}^{2}$ \\
\hline Anchovy & & \\
$\log$ Prot $=1.098 \log \mathrm{OM}-0.727$ & $1.079-1.119$ & 0.995 \\
$\log \mathrm{CH}=0.896 \log \mathrm{OM}-1.049$ & $0.748-1.044$ & 0.731 \\
$\log \mathrm{Lip}=0.915 \log \mathrm{OM}-0.294$ & $0.865-0.966$ & 0.809 \\
$\log \mathrm{DNA}=1.071 \log \mathrm{OM}+2.165$ & $1.033-1.108$ & 0.985 \\
$\log \mathrm{RNA}=1.143 \log \mathrm{OM}-2.111$ & $1.029-1.257$ & 0.981 \\
Sardine & & \\
$\log$ Prot $=1.098 \log \mathrm{OM}-0.652$ & $1.079-1.119$ & 0.995 \\
$\log \mathrm{CH}=0.688 \log \mathrm{OM}+0.228$ & $0.568-0.807$ & 0.826 \\
$\log \mathrm{Lip}=0.886 \log \mathrm{OM}-0.160$ & $0.835-0.938$ & 0.977 \\
$\log \mathrm{DNA}=1.071 \log \mathrm{OM}+2.165$ & $1.033-1.108$ & 0.985 \\
$\log \mathrm{RNA}=1.218 \log \mathrm{OM}-2.412$ & $1.155-1.281$ & 0.974 \\
Horse mackerel & & \\
$\log$ Prot $=1.008 \log \mathrm{OM}-0.189$ & $0.975-1.037$ & 0.993 \\
$\log \mathrm{CH}=0.896 \log \mathrm{OM}-1.049$ & $0.748-1.044$ & 0.731 \\
$\log \mathrm{Lip}=0.915 \log \mathrm{OM}-0.294$ & $0.865-0.966$ & 0.809 \\
$\log \mathrm{DNA}=0.847 \log \mathrm{OM}-0.920$ & $0.749-0.956$ & 0.923 \\
$\log \mathrm{RNA}=1.223 \log \mathrm{OM}-2.412$ & $1.164-1.284$ & 0.974 \\
\hline
\end{tabular}


culated 2 equations with equal slopes but 2 different intercepts (Table 2). Finally, as the intercepts of the equations relating RNA to OM were not significantly different for sardine and horse mackerel, 2 equations, with equal intercepts but different slopes, were calculated (Table 2).

The allometric relationships between biochemical constituents and OM were consistent in anchovy and sardine, but sometimes differed from those of horse mackerel. In the 3 species, the highest slopes were found for RNA, followed by proteins. However, in anchovy and sardine these slopes were followed by DNA, lipids and finally carbohydrates, while in horse mackerel they were followed by lipids, carbohydrates and DNA (Table 2). For the 3 species, there was a clearly positive allometry with OM (slope > 1) in RNA, and a slightly positive allometry in proteins. Also in the 3 species, there was a negative allometry in lipids. However, in horse mackerel the slope of proteins was so close to 1 that the confidence interval included values below 1 ; thus, it is conceivable that protein content varies isometrically with OM. Finally, DNA showed a slightly positive allometry in anchovy and sardine, but a negative one in the case of horse mackerel.

A rectangular hyperbola - an asymptotic function-best described the relationship between the percentage of a biochemical constituent and the total OM content in anchovy and sardine (Fig. 4). The relationship between protein percentage and OM was initially positive and became asymptotic when protein content reached $74 \%$ of OM in anchovy and $75.6 \%$ of $\mathrm{OM}$ in sardine. The percentages of carbohydrates and lipids decreased as the OM increased: carbohydrates became constant at $2.1 \%$ of OM in anchovy and at $3.7 \%$ of OM in sardine. Lipids became asymptotic when they reached $21.0 \%$ of OM in anchovy and $16.1 \%$ in sardine. The back-calculated OM content and length at which larvae reached the 95\% of the asymptotic percentage values of each biochemical constituent corresponded to a higher OM content, longer SL and a more advanced ontological stage in the case of anchovy compared to sardine (Table 3).
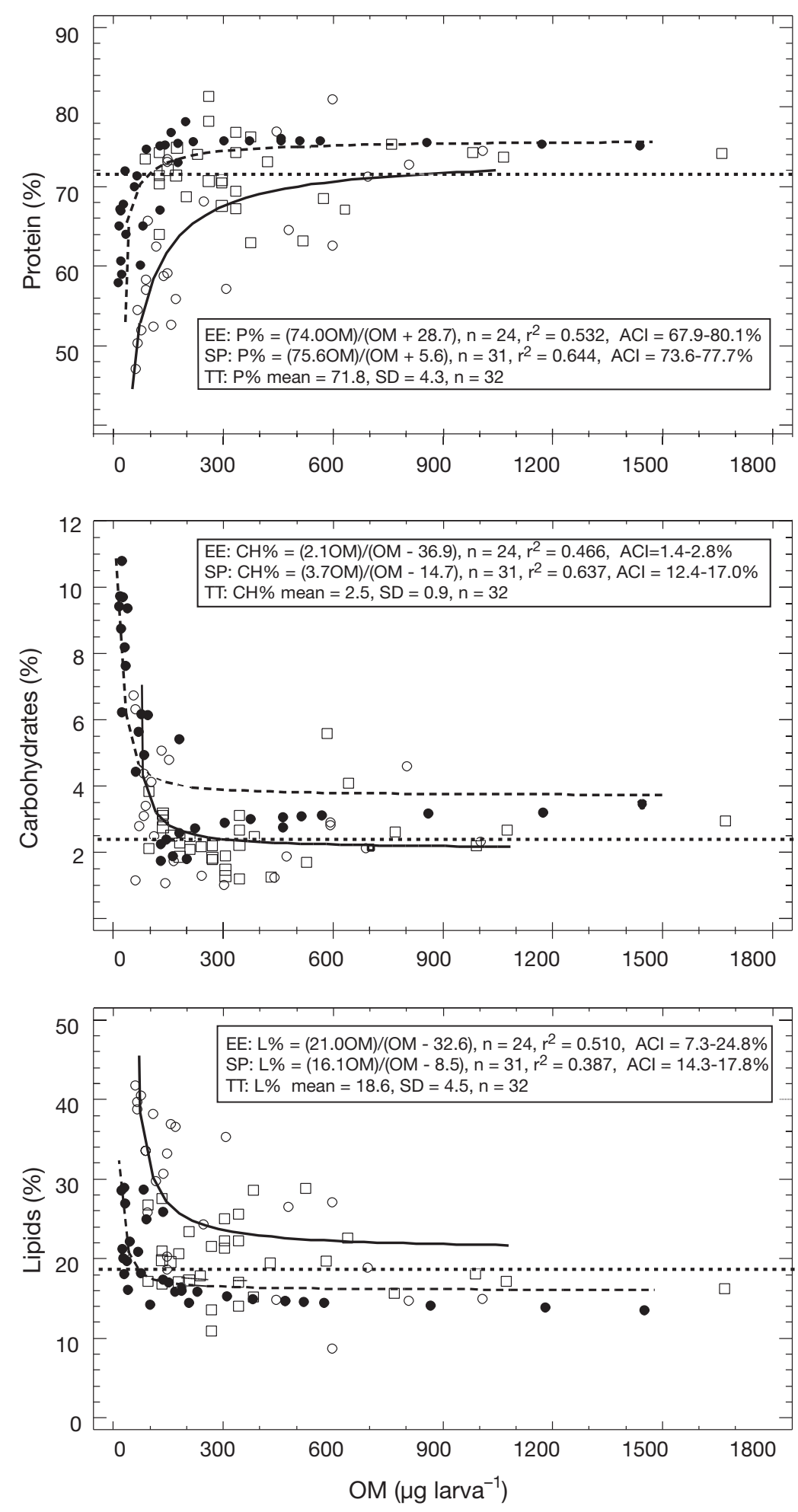

Fig. 4. Engraulis encrasicolus (EE, O, - ), Sardina pilchardus (SP, $---)$ and Trachurus trachurus (TT, $\square, \cdots \cdot \cdot$ ). Relationship of the percentage of each biomolecule with the organic matter (OM) content of larvae (see explanation in 'Data treatment'). ACI: Asympotic 95\% confidence interval; $\mathrm{SD}$ : standard deviation; $\mathrm{P} \%$ : protein percentage; $\mathrm{CH} \%$ : carbohydrate percentage; $\mathrm{L} \%$ : lipid percentage 
Table 3. Engraulis encrasicolus and Sardine pilchardus. Calculation of the mean $( \pm \mathrm{SD})$ organic matter $(\mathrm{OM})$ content and standard length (SL) at which larvae reach $95 \%$ of the asymptotic value of each biomolecule. To transform OM content into $\mathrm{SL}$, the following equations were used: anchovy $\mathrm{SL}=$ $\ln [(\mathrm{OM} / 0.0094) / 0.3234]$; sardine $\mathrm{SL}=\ln [(\mathrm{OM} / 0.0015) / 0.4120]$

\begin{tabular}{|lcc|}
\hline & $\begin{array}{c}\text { Corres- } \\
\text { ponding OM } \\
\left(\mu \text { larva }^{-1}\right)\end{array}$ & $\begin{array}{c}\text { Corres- } \\
\text { ponding } \\
\text { SL }(\mathrm{mm})\end{array}$ \\
\hline Anchovy & & \\
$\mathrm{P} \%=(74.0 \mathrm{OM}) /(\mathrm{OM}+28.7)$ & 545 & 12.6 \\
$\mathrm{CH} \%=(2.1 \mathrm{OM}) /(\mathrm{OM}-36.9)$ & 738 & 13.5 \\
$\mathrm{~L} \%=(21.0 \mathrm{OM}) /(\mathrm{OM}-32.6)$ & 652 & 13.1 \\
Sardine & & \\
$\mathrm{P} \%=(75.6 \mathrm{OM}) /(\mathrm{OM}+5.6)$ & 106 & 10.3 \\
$\mathrm{CH} \%=(3.7 \mathrm{OM}) /(\mathrm{OM}-14.7)$ & 294 & 12.8 \\
$\mathrm{~L} \%=(16.1 \mathrm{OM}) /(\mathrm{OM}-8.5)$ & 170 & 11.5 \\
\hline
\end{tabular}

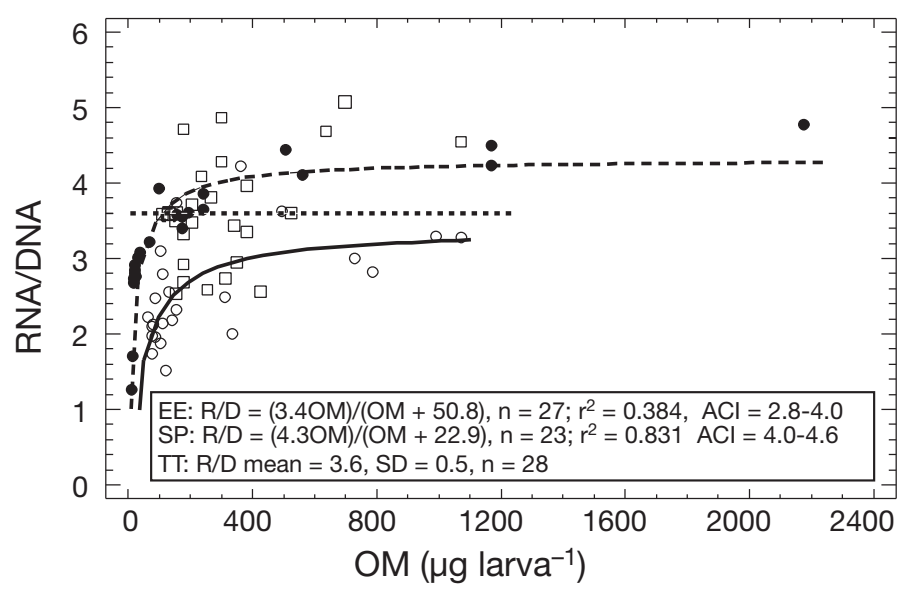

Fig. 5. Engraulis encrasicolus (EE, $\mathrm{O},-$ ), Sardina pilchardus (SP, $\bullet,---)$ and Trachurus trachurus (TT, $\square, \cdots \cdot \cdot$ ). Relationship of the RNA/DNA ratio and organic matter (OM) content of larvae (See explanation in Data treatment). ACI: Asympotic $95 \%$ confidence interval; SD: standard deviation

The relationship between the RNA/DNA ratio and OM content also took the shape of a rectangular hyperbola in the case of anchovy and sardine, and it became asymptotic when the index reached values of 3.4 and 4.3, respectively (Fig. 5). In horse mackerel, it was not possible to fit the data to an hyperbolic model due to the high variability of biochemical composition and RNA/DNA ratios in the smallest larvae. Nevertheless, the percentages and the RNA/ DNA ratio stabilized in the largest larvae (Figs. $4 \& 5$ ). The average values for each biomolecule percentage and RNA/DNA index in postflexion larvae were very close to the asymptotic values of the clupeoids: $\mathrm{P} \%=71.1, \mathrm{CH} \%=2.4 \%, \mathrm{~L} \%=$ $19.1 \%$ and RNA/DNA $=3.8$.

The biochemical composition of larvae in the notochord flexion stage, modelled according to the equations relating biomolecule percentage to $\mathrm{OM}$ in anchovy and sardine, were very similar to the average values in the size range around nothocord flexion (5.75 to $6.25 \mathrm{~mm}$ ) in horse mackerel (Table 4). In all 3 species, proteins were the main larval component, followed by lipids and carbohydrates.

Differences between the specific growth trajectory and morphology of anchovy and sardine larvae on the one hand and those of the horse mackerel larvae on the other were evident from the very first larval stage. For a given size, horse mackerel larvae were much heavier than those of anchovy and sardine (Table 5; Fig. 2). The larvae of clupeoids, belonging to the eellike shape group (Froese 1990, Estensoro 2006), have low weights but large body lengths, while this relationship is inverted in horse mackerel larvae, belonging to the tadpole-like group (Froese 1990, Estensoro 2006). Growth rates are higher in clupeoids than in horse mackerel (Estensoro 2006), with $0.47 \mathrm{~mm} \mathrm{~d}^{-1}$ in anchovy and $0.70 \mathrm{~mm} \mathrm{~d}^{-1}$ in sardine, compared to $0.20 \mathrm{~mm} \mathrm{~d}^{-1}$ in horse mackerel. Consequently, all ontological events occur at a similar age but at a longer SL in clupeoids compared to horse mackerel (Table 5).

The relationship between RNA/DNA ratio and SL was significant for the 3 species (Fig. 6). The intercept of the equation relating RNA/DNA ratio to SL was significantly different in the 3 species $(F=45.2, \mathrm{p}<$ $0.0001)$, but not in the case of the slope $(F=1.3, \mathrm{p}=$ 0.2795). Therefore, 3 regression equations with equal slope but different intercepts were calculated to relate RNA/DNA ratio to SL (Fig. 6). The slopes of the regressions of anchovy (slope $=3.22 ; \mathrm{CI}=3.0$ to 3.4 ) and sardine (slope $=4.67$; $\mathrm{CI}=4.5$ to 4.8 ) coincide closely with the asymptotic values predicted by the hyperbolic mod-

Table 4. Engraulis encrasicolus, Sardina pilchardus and Trachurus trachurus. Calculation of biochemical composition and RNA/DNA index at flexion stage, using the average values for the 5.75 to $6.25 \mathrm{~mm}$ size range in the case of horse mackerel and the hyperbolic functions in the case of anchovy and sardine. SL: standard length; OM: organic matter; Prot: proteins; $\mathrm{CH}$ : carbohydrates; Lip: lipids

\begin{tabular}{|lcccccc|}
\hline & SL $(\mathrm{mm})$ & $\mathrm{OM}\left(\mu \mathrm{g} \mathrm{larva}^{-1}\right)$ & Prot $(\%)$ & $\mathrm{CH}(\%)$ & Lip $(\%)$ & RNA/DNA \\
\hline Anchovy & 9.5 & 213.9 & $67.0 \pm 7.4$ & $2.6 \pm 1.0$ & $24.9 \pm 5.3$ & $2.8 \pm 0.7$ \\
Sardine & 11.5 & 167.2 & $73.2 \pm 2.5$ & $3.9 \pm 0.8$ & $16.4 \pm 2.1$ & $3.8 \pm 0.3$ \\
Horse mackerel & 6 & 277.7 & $73.5 \pm 4.9$ & $1.8 \pm 0.3$ & $17.5 \pm 5.0$ & $3.3 \pm 0.6$ \\
\hline
\end{tabular}


Table 5. Engraulis encrasicolus, Sardina pilchardus and Trachurus trachurus. Standard length (SL) of each ontogenic event in larvae according to Russell (1976), and the calculated OMs and age that correspond to these stages. OM content was calculated using the equations of the present study relating OM to SL when the SL of a determinate stage was within the size range of larvae included in the present study. When the SL was out of the range this is indicated as 'na' (not applicable). Age was estimated using the average growth rates, calculated for Estensoro (2006) in the same study area using larvae that covered the same size range as the present study (anchovy: $0.47 \mathrm{~mm} \mathrm{~d}^{-1}$; sardine: $0.70 \mathrm{~mm} \mathrm{~d}^{-1}$; horse mackerel: $0.20 \mathrm{~mm} \mathrm{~d}^{-1}$ )

\begin{tabular}{|lccc|}
\hline & SL $(\mathrm{mm})$ & OM $\left(\right.$ larva $\left.^{-1}\right)$ & Age (d) \\
\hline Anchovy & & & \\
Egg size & 1.2 to $1.9 \times 0.5$ to 1.2 & & \\
Yolk absorption & $4-5$ & na & $1-3$ \\
Swim-bladder formation & 7 & 90 & 7 \\
Flexion notochord & $9.0-10.0$ & $173-239$ & $12-14$ \\
Appearance of pelvic fins & 15 & 1203 & 24.6 \\
Sardine & & & \\
Egg size & $1.3-1.9$ & & \\
Yolk absorption & $4.0-5.5$ & na & $1-2$ \\
Swim bladder formation & 10 & 92.4 & 8 \\
Notochord flexion & $11-12.5$ & $140-259$ & $10-12$ \\
Appearance of pelvic fins & $20-22$ & na & $23-25$ \\
Horse mackerel & & & \\
Egg size & $0.8-1.0$ & & $3-7$ \\
Yolk absorption & $2.6-3.2$ & na & 10 \\
Swim bladder formation & 4 & 268.7 & $18-19$ \\
Notochord flexion & 6 & $428-640$ & $25-31$ \\
Appearance of pelvic fins & $7-8$ & & \\
\hline
\end{tabular}

mackerel and sardine (intercept: $F=6.2$, $\mathrm{p}=0.0164$, slope: $F=0.1, \mathrm{p}=0.8054), 2$ equations with the same slope but a different intercept were calculated for these 2 species (Fig. 6). The slope of the equation relating RNA to DNA content of anchovy was significantly lower than that of the sardine and horse mackerel.

\section{DISCUSSION}

The differences in morphological, physiological and behavioural characteristics between sardine, anchovy and horse mackerel co-occur with differing energy allocation strategies related to growth. These different strategies could affect the ability of larvae to avoid predators and obtain resources to grow and survive until the next life-history stage. Anchovy and sardine showed similar trends in the variation of their biochemical composition during growth, but they differed considerably from those of horse mackerel.

Guisande et al. (1998) and Riveiro (2002) found the same biochemical trends in anchovy and sardine as those

els for RNA/DNA ratio versus OM content in a larva: RNA/DNA $=3.4$ and $\mathrm{ACI}=2.8$ to 4.0 for anchovy, and $\mathrm{RNA} / \mathrm{DNA}=4.30$ and $\mathrm{ACI}=4.0$ to 4.6 for sardine.

The relationship between RNA and DNA content among the 3 species was significantly different, both in the intercept and the slope (Fig. 7) (intercept: $F=17.4$, $\mathrm{p}<0.0001$, slope: $F=49.8, \mathrm{p}<0.0001)$. However, as the slope was not significantly different between horse

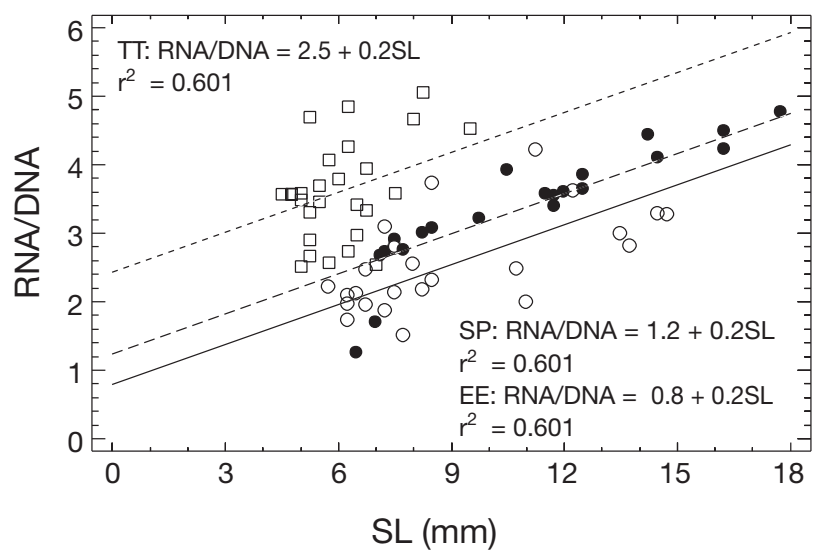

Fig. 6. Engraulis encrasicolus (EE, O, -), Sardina pilchardus (SP, $\bullet,--)$ and Trachurus trachurus (TT, $\square,---)$. Relationship between RNA/DNA ratio and standard length (SL) of larvae identified in the present study, i.e. a positive relationship between protein percentage with SL, together with a negative relationship of SL with lipids and carbohydrates. In contrast, in the case of horse mackerel, they did not find any dependence of protein and lipid percentages on SL. The relative increase of proteins and the decrease of lipids with increasing size of anchovy and sardine larvae conform to the definition

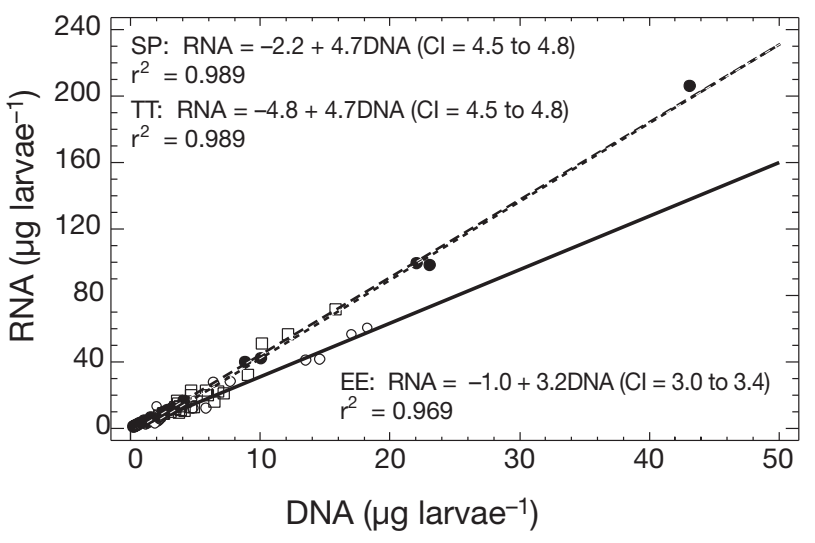

Fig. 7. Engraulis encrasicolus (EE, $\mathrm{O},-$ ), Sardina pilchardus (SP, $\bullet,---)$ and Trachurus trachurus (TT, $\square,---)$. Relationship between RNA and DNA content. CI: 95\% confidence interval 
of 'Type 1' larvae put forward by Pfeiler (1986). The overall strategy of the Type 1 larva can be summarised as: (1) to maximise growth and minimise the duration of the larval phase; (2) to shorten the time expended in the size-classes more exposed to predation (Folkvord \& Hunter 1986, Rice et al. 1993); and (3) to increase the locomotive capabilities and, therefore, prey spectrum (Blaxter \& Hempel 1963). Muscle, which is composed mostly of protein, is a key tissue influencing larval growth and it is linked directly to locomotory capacity and floatability. 'Type 1' larvae show energy allocation strategies that fit with the 'growth-mortality' hypothesis, as already hypothesized for sardines (Ramírez et al. 2001, Alemany et al. 2006).

According to the trends in the biochemical composition during growth, horse mackerel does not have Type 1 larvae. Owing to their morphological and physiological characteristics, horse mackerel larvae may not need to grow as fast as clupeoids to reduce potential predation and/or starvation risks during their initial developmental phases. In fact, perciforms (the order to which horse mackerel belongs) reach developmental milestones at smaller sizes than clupeoids (Leis 2006). For a given SL, eel-like larvae swim more slowly (Blaxter \& Hunter 1982) and have smaller heads and mouths (Estensoro 2006) than tadpole-like larvae. Hence, as a result of their greater swimming ability, larvae of horse mackerel might be more efficient than clupeoid larvae of the same SL both in capturing prey and in escaping from predators. For example, larvae of the jack mackerel Trachurus japonicus, a congeneric species to horse mackerel, have much greater predation avoidance ability than that of clupeoid larvae (Lenarz 1973). Additionally, their bigger mouths allow horse mackerel larvae to have a broader prey spectrum and permits the consumption of large, energetically profitable prey items, which allows larvae to shift to higher trophic levels earlier in their life (Schmitt \& Holbrook 1984, Stergiou \& Fourtouni 1991). Swimming ability to escape and to forage (Bailey \& Batty 1984), as well as mouth size (Karpouzi \& Stergiou 2003, Estensoro 2006), increases with larval size. More specifically, larvae are specialized predators that may get immediate benefit from giving high priority to the development of feeding (Osse \& van den Boogaart 1999) and locomotory structures. Thus, in all species, larger larvae would have higher survival probabilities, but these increases should be more important in eellike larvae due to their initially lower swimming abilities and smaller mouths. The cruising speed of sardines increases from 10 to $30 \mathrm{~cm} \mathrm{~min}{ }^{-1}$ over $3 \mathrm{wk}$ (Blaxter \& Staines 1971), whilst the feeding success of anchovy increases from 10 to $90 \%$ over the same time period (Hunter 1972). Therefore, the strategy of increasing the allocation of resources to maximize growth rate of somatic structures related to larval swimming and feeding is probably the optimum growth strategy for clupeoids, at least until the building up of reserves to cope with periods of negative energetic balance becomes necessary. In contrast, the absence of any clear trend in the biochemical composition of horse mackerel larvae seems to indicate that the standard larva has, from the very beginning, a proportion of biochemical components that meets the requirements for sustaining optimal growth and that, after an initial stage of high variability, quickly becomes stable and remains stable up to greater larval sizes than those analysed in this study.

The SL at which $95 \%$ of the asymptotic value of a biochemical constituent are reached is similar in sardine and anchovy, but this size corresponds to a less advanced ontogenetic stage (Ré 1984, 1996), weight and age in sardine than in anchovy. In sardine, $95 \%$ of the asymptotic values are achieved in larvae with a SL corresponding to a flexion larva ( $\mathrm{SL}=11.3$ to $12.2 \mathrm{~mm}$ ) (Ré 1996), while the same percentage in anchovy is reached in postflexion larvae ( $\mathrm{SL}=11.6$ to $12.5 \mathrm{~mm}$ ) (Ré 1996). Furthermore, as the average growth rate of sardines is higher than that of anchovy (sardine $0.70 \mathrm{~mm} \mathrm{~d}^{-1}$, anchovy: $0.47 \mathrm{~mm} \mathrm{~d}^{-1}$; Estensoro 2006), sardines would need less time (10 to $12 \mathrm{~d})$ than anchovy (17 to $19 \mathrm{~d}$ ) to reach their respective asymptotic values. So, although the asymptotic biochemical composition is similar in both species, this composition will be attained at different weights and ages depending on the ontogeny of each species. Metamorphosis begins in sardine at an age of about $40 \mathrm{~d}$ and in anchovy around 37 d (Houde \& Zastrow 1993). Consequently, percentages in biochemical components very close to the presumed optimum (i.e. corresponding to $95 \%$ of the asymptotic value) seem to be reached well before the beginning of metamorphosis.

Although the larvae of clupeoids and horse mackerel show different trends in their biochemical composition during early growth, the relative amounts of biomolecules become similar in older larvae. This indicates that, during ontogeny, there may be convergences in the larval biochemical composition of different species. Proteins are the main organic component in flexionstage larvae, followed by lipids and, finally, carbohydrates, as observed in other fish larvae (Ehrlich 1974a, Cetta \& Capuzzo 1982, Donnelly et al. 1995).

The relative amounts of biomolecules and the RNA/DNA ratio at which asymptotic values are reached will reflect the 'optimal proportions' of biomolecules in anchovy and sardine (Díaz et al. 2008). Furthermore, it looks as if the 'optimal proportion' values, derived from the asymptotic approach, were functionally equivalent to the 'stabilisation' values found in horse mackerel. Similarly, it appears that different spe- 
cies tend to have a similar biochemical composition at the end of their larval development, but that each species would reach this 'consensus' biochemical composition using different strategies and following different trajectories depending on their primary (at hatching) biochemical characteristics. In this sense, Vila-Gispert \& García-Berthou (2002) studied the early life history of 301 fish species from all over the world and concluded that, despite phylogenetic constraints, basic life history patterns showed consistency among distant geographic regions, latitudinal ranges and basic adult habitats, indicating convergences in life history patterns.

Almost certainly, both the energy allocation strategy and the optimal value of the RNA/DNA ratio will change in larvae across ontogenetic stages. Energy storage levels of the earliest larvae will probably remain low because they will be more compelled to invest energy in growing by hyperplasy than the more developmentally advanced larvae. Once larvae develop all anatomical characteristics needed for efficient swimming, they are better suited to escape predators and to find and capture prey. Consequently, during this stage, they do not need to growth as fast and can invest in energy storage, i.e. growing by hypertrophy could increase survival more than continued investment in hyperplasic growth. The decrease in the overall growth rate with age in late larvae is reflected in a decrease in RNA/DNA ratios in late larvae and juveniles (Fonseca et al. 2006, Vinagre et al. 2008). Therefore, a slower-growing older larva may be in equally good condition as a faster-growing younger larvae (Chícharo \& Chícharo 2008). Thus, it is essential to determine the relation of the RNA/DNA ratio with size or age under different conditions to interpret the physiological meaning of a determinate RNA/DNA value and to assess the condition of the larvae at each stage.

The similarity of the slopes in the RNA versus DNA regression for anchovy and sardine with the asymptotic values predicted by the hyperbolic models of RNA/DNA ratio versus OM content shows that the slope of this regression in a larval population of individuals of different sizes, but at similar ontogenetic stages, is equivalent to the value of the RNA/DNA ratio at which it becomes stable during larval growth. In addition, the fact that the slope of the regression for horse mackerel is identical to that for sardine would indicate that the slope's value is not significantly different from the asymptotic value of an eventual hyperbola at which experimental data of RNA/DNA ratio versus OM would be fitted in horse mackerel. Moreover, arithmetical media of RNA/DNA ratios in postflexion larvae of horse mackerel enter into the confidence interval of the asymptotic value of the hyperbola for sardine larvae. Thus, by comparing the actual value of the RNA/DNA ratio found in an individual larva with the value of the slope of the regression of RNA versus DNA contents in a given population, we should be able to assess its condition.

By showing the relation between a given energy allocation strategy and its potential ecological advantages depending on the fish larvae morphology, the results of the present study demonstrate the importance of the analysis of biochemical data. Our conclusions confirm the results of Guisande et al. (1998) and Riveiro (2002) regarding the different energy allocation strategies in clupeoids and horse mackerel. However, it is the very first time that larval morphology has been related to a different energy allocation strategy. For that reason, we propose caution when interpreting divergences in biochemical composition during development as being related to different energy allocation strategies in the 2 differing larval morphologies treated in this work, namely, the eel-like and the tadpole-like larval groups.

The morphology of a fish larva is determined by its phylogenetic roots no less than by the environmental parameters to which it is exposed. It must be kept in mind that fish larvae, despite being morphologically simple, are in fact creatures highly adapted to interact successfully with the complex and dynamic environment in which they must develop (Fuiman 1996). As a consequence, an enormous disparity of situations exists. Larvae that are morphologically very similar, e.g. leptocephalus larvae (a kind of eel-like larva), may be of phylogenetically different origin, like the larvae of the orders Anguilliformes and Elopiformes, while closely related species of the genus Hygophum (Teleostei: Myctophidae) show 3 different larval morphologies (Yamaguchi et al. 2000). This makes any attempt to clarify which factor affects the actual morphology of a larva profoundly difficult: (1) the driving force behind the general pattern of phylogenetic canalization of the larval development or (2) the specific ontogenetic change of any kind (e.g. morphological, biochemical, behavioural) that, by modifying the performance of a larva, would improve its level of adaptation to the particular environment where it lives (Fuiman 1996).

However, to understand the interactions between morphology, phylogeny, environment and the energy allocation strategy, it would be necessary to broaden this kind of study to different morphological types and species of larvae. Firstly, more larvae of the same body shape and taxonomic family should be examined to increase the number of replicates, especially in the case of tadpole-like larvae. Secondly, larvae of the same morphological group that are phylogenetically distant or, vice versa, belonging to the same taxonomic 
group but differing in larval morphology should be examined to prove that the strategies are linked to body shape and not to other factors, or that they are more closely connected with body shape than with other factors. Moreover, the changes in biochemical composition during growth of these species under other environmental conditions and locations should be examined to strengthen the results of the present study. In fact, larval composition could change based on parental effect (Riveiro et al. 2000, Díaz et al. 2008) and environmental conditions, principally temperature and food availability (Buckley 1982, García et al. 2006). Finally, it would be of great interest to measure the biochemical composition in bigger larvae and juveniles of these 3 species to examine the eventual changes in energy allocation strategies during more advanced developmental stages.

Acknowledgements. E.D. was supported by a grant from the Department of Education, Universities and Research of the Basque Government and the study by the Spanish Ministry of Science and Technology (MAR1999-0328-C03-02). We are grateful to M. Collins from the University of Southhampton and AZTI-Tecnalia for the language revision of the manuscript, and to 3 anonymous referees for their useful comments. This paper is contribution no. 438 from AZTI-Tecnalia (Marine Research).

\section{LITERATURE CITED}

Alemany F, Álvarez I, García A, Cortés D and others (2006) Postflexion larvae and juvenile daily growth patterns of the Alborán Sea sardine (Sardina pilchardus Walb.): influence of wind. Sci Mar 70:93-104

> Amenzoui K, Ferhan-Tachinante F, Yahyaoui A, Kifani S, Mesfioui A (2006) Analysis of the cycle of reproduction of Sardina pilchardus (Walbaum, 1792) off the Moroccan Atlantic coast. C R Biol 329:892-901

Bailey KM, Batty R (1984) Laboratory study of predation by Aurelia aurita on larvae of cod, flounder, plaice and herring: development and vulnerability to capture. Mar Biol 83:287-291

Belchier M, Clemmesen C, Cortés D, Doan L, Folkvord T, García A, Geffen A, Høie H, Johannessen A, Mokness E, de Pontual H, Ramírez T, Schnack D, Sveinsbo B (2004) Recruitment studies: manual on precision and accuracy of tools. ICES Tech Mar Environm Sci 33:35 pp <

Blaxter JHS, Hempel G (1963) The influence of egg size on herring larvae (Clupea harengus L.). J Cons Perm Int Explor Mer 28:211-240

Blaxter JS, Hunter JR (1982) The biology of clupeoid fishes. Adv Mar Biol 20:1-223

Blaxter JHS, Staines ME (1971) Food searching potential in marine fish larvae. In Crisp DJ (ed) 4th European Marine Biology Symp. Cambridge University Press, Cambridge, p 467-485

Bligh EG, Dyer WJ (1959) A rapid method for total lipid extraction and purification. Can J Biochem Physiol 37: 911-917

> Buckley LJ (1982) Effects of temperature on growth and biochemical composition of larval winter flounder, Pseudopleuronectes americanus. Mar Ecol Prog Ser 8:181-186

Caldarone EM (2005) Estimating growth in haddock larvae
Melanogrammus aeglefinus from RNA:DNA ratios and water temperature. Mar Ecol Prog Ser 293:241-252

Cetta CM, Capuzzo JM (1982) Physiological and biochemical aspects of embryionic and larval development of the winter flounder Pseudopleuronectes americanus. Mar Biol 71: $327-337$

Chícharo MA, Chícharo L (2008) RNA:DNA ratio and other nucleic acid derived indices in marine ecology. Int $\mathrm{J}$ Mol Sci 9:1453-1471

Cushing DH (1990) Recent studies on long-term changes in the sea. Freshw Biol 23:71-84

Díaz E (2008) Condition and biochemical composition of three pelagic larvae in the Bay of Biscay: Engraulis encrasicolus, Sardina pilchardus and Trachurus trachurus. $\mathrm{PhD}$ dissertation, University of the Basque Country, Bilbao

> Díaz E, Valencia V, Villate F (2007) Size-fractionated seston abundance and biochemical composition, over the anchovy spawning period in the Basque shelf (Bay of Biscay), during years 2000 and 2001. J Exp Mar Biol Ecol 341: $45-59$

> Díaz E, Txurruka JM, Villate F (2008) Biochemical composition and condition in anchovy larvae (Engraulis encrasicolus) during growth. Mar Ecol Prog Ser 361:227-238

Donnelly J, Torres J, Crabtae R (1995) Proximate composition and nucleic acid content of premetamorphic leptocephalus larvae of the congrid eel Ariosoma balearicum. Mar Biol 123:851-858

Dubois M, Gilles KA, Hamilton JK, Rebers PA, Smith F (1956) Colorimetric method for determination of sugar and related substances. Anal Chem 28:350-356

- Ehrlich KF (1974a) Chemical changes during growth and starvation of larval Pleuronectes platessa. Mar Biol 24:39-48

Estensoro I (2006) Comparative analysis of five fish larvae species morphology in relationship with their feeding strategies. Thesis for Master of marine and lacustrine sciences. Gent University

Esteves E, Pina T, Chícharo MA, Andrade P (2000) The distribution of estuarine fish larvae: Nutritional condition and co-occurrence with predators and prey. Acta Oecol 21: 161-173

Folkvord A, Hunter JR (1986) Size specific vulnerability of northern anchovy (Engraulis mordax) larvae to predation by fishes. Fish Bull US 84:859-869

Fonseca V, Vinagre C, Cabral HN (2006) Growth variability of juvenile soles Solea solea and Solea senegalensis, and comparison with RNA:DNA ratios in the Tagus estuary, Portugal. J Fish Biol 68:1551-1562

Froese R (1990) Growth strategies of fish larvae. International Council on the Exploration of the Sea (ICES) CM L:1-20 http://filaman.uni-kiel.de/ifmgeomar/rfroese/growth\%20 strategies.pdf

Fuiman LA (1996) Preface: Dynamic morphology, physiology and behaviour of fish larvae. Mar Freshwat Behav Physiol 28:1-2

> Gagliano M, McCormick MI, Meekan MG (2007) Survival against the odds: ontogenetic changes in selective pressure mediate growth-mortality trade-offs in a marine fish. Proc R Soc Lond B Biol Sci 274:1575-1582

García A, Cortés D, Ramírez R, Guisande C and others (2006) Field comparison of sardine post-flexion larval growth and biochemical composition from three sites in the W Mediterranean (Ebro river coast, bays of Almería and Málaga). Sci Mar 70:79-91

Guisande C, Riveiro I, Sola A, Valdés L (1998) Effect of biotic and abiotic factors on the biochemical composition of wild eggs and larvae of several fish species. Mar Ecol Prog Ser 163:53-61 
Hare J, Cowen R (1997) Size, growth, development and survival of the planktonic larvae of Pomatomus saltatrix (Pisces: Pomatomidae). Ecology 78:2415-2431

Houde ED (1987) Fish early dynamics and recruitment variability. Am Fish Soc Symp 2:17-29

Houde ED, Zastrow CE (1993) Ecosystem- and taxon-specific dynamic energetics properties of fish larvae assemblages. Bull Mar Sci 53:290-335

Hunter JR (1972) Swimming and feeding behaviour of larval anchovy Engraulis mordax. Fish Bull US 70:821-838

Karpouzi VS, Stergiou K (2003) The relationships between mouth size and shape and body length for 18 species of marine fishes and their trophic implications. J Fish Biol 62:1353-1365

Last JM (1980) The food of twenty species of first larvae in the west central North Sea. Fish Res Tech Rep 60:1-44

Leggett WC, Debois E (1994) Recruitment in marine fishes: is it regulated by starvation and predation in the egg and larval stages? Neth J Sea Res 32:119-134

Lenarz WH (1973). Dependence of catch rates on size of fish larvae. Rapp Reun Con int Explor Mer 164:270-275

Lowry OH, Rosebrough NJ, Farr AL, Randall RJ (1951) Protein measurement with the Folin-phenol reagent. J Biol Chem 87:206-210

Markwell MK, Haas SM, Bieber LL, Tolbert NE (1978) A modification of the Lowry procedure to simplify protein determination in membrane and lipoprotein samples. Anal Chem 87:206-210

Miller TJ, Crowder LB, Rice JA, Marschall EA (1988) Larval size and recruitment mechanisms in fishes: toward a conceptual framework. Can J Fish Aquat Sci 45:1657-1670

Nursall JR (1989) Buoyancy is provided by lipids of larval redlip blennies, Opioblennius atlanticus (Teleostei: Blenniidae). Copeia 1989:614-621

Osse JWM, van den Boogaart JGM (1999) Dynamic morphology of fish larvae, Structural implications of friction forces in swimming, feeding and ventilation. J Fish Biol 55: 156-174

Palomera I (1991) Vertical distribution of eggs and larvae of Engraulis encrasicolus in stratified waters of the western Mediterranean. Mar Biol 111:37-44

Pfeiler E (1986) Towards an explanation of the developmental strategy in lectocephalous larvae of marine teleost fishes. Environ Biol Fishes 15:3-13

Post JR, Parkinson EA (2001) Energy allocation strategy in young fish: Allometry and survival. Ecology 82:1040-1051

Ramírez T, Cortes D, García A (2001) Growth of North Alboran Sea sardine larvae estimated by otolith microstructure, nucleic acids and protein content. J Fish Biol 59:403-415

Editorial responsibility: Jon Hare, Narragansett, Rhode Island, USA
Ré P (1984) Evidence of daily and hourly growth in pilchard larvae based on otolith growth increments, Sardina pilchardus (Walbaum, 1792). Cybium 8:33-38

Ré P (1996) Anchovy spawning in the Mira estuary (southwestern Portugal). Sci Mar 60:141-153

Rice JA, Miller TJ, Rose K, Crowder LB, Marschall EA, Trebitz AS, DeAngelis DL (1993) Growth rates variation and larval survival: inference from an individual based size-dependent prestation model. Can J Fish Aquat Sci 50:1690-1698

Riveiro I (2002) Estrategias parentales de la sardina atlántica (Sardina pilchardus) en la Península Ibérica. PhD dissertation, University of Vigo

Riveiro I, Guisande C, Lloves M, Maniero I, Cabanas JM (2000) Importance of parental effects on larval survival in Sardina pilchardus. Mar Ecol Prog Ser 205:249-258

Russell FS (1976) The eggs and planktonic stages of British marine fishes. Academic Press, London

Schmitt RJ, Holbrook SJ (1984) Ontogeny of prey selection by black surfperch Embiotoca jacksoni (Pisces: Embiotocidae): the roles of fish morphology, foraging behaviour, and patch selection. Mar Ecol Prog Ser 18:225-239

Sharp GD, McLain DR (1993) Fisheries, El Nino-Southern Oscillation and upper Ocean temperature records: an eastern pacific example. Oceanography 6:13-22

Southward AJ, Boalch GT, Mattock L (1988) Fluctuations in the herring and pilchard fisheries of Devon and Cornwall linked to change in climate since the 16th century. J Mar Biol Assoc UK 68:423-445

Stergiou KI, Fourtouni H (1991) Food habits, ontogenetic diet shift and selectivity in Zeus faber Linnaeus, 1758. J Fish Biol 39:589-603

> Vila-Gispert MAR, García-Berthou E (2002) Gradients of lifehistory variation: an intercontinental comparison of fishes. Rev Fish Biol Fish 12:417-427

Vinagre C, Fonseca V, Cabral HN (2008) Habitat specific growth rates and condition indices for the sympatric soles Solea solea (Linnaeus, 1758) and Solea senegalensis (Kaup 1858), in the Tagus estuary, Portugal, based on otolith daily increments and RNA-DNA ratio. J Appl Ichthyology 24:163-169

> Yamaguchi M, Miya M, Okiyama M, Nishida M (2000) Molecular phylogeny and larval morphological diversity of the lanternfish genus Hygophum (Teleostei: Myctophidae). Mol Phyl Evol 15:103-114

Zöllner N, Kirsch K (1962) Über die quantitative Bestimmung von Lipoiden (Mikromethode) mittels der vielen natürlichen Lipoiden (allen bekannten Plasmalipoiden) gemeinsamen Sulphosphovainillin. Z Gesamte Exp Med 135:545-561

Submitted: May 20, 2008; Accepted: January 21, 2009 Proofs received from author(s): April 10, 2009 